\title{
Arabidopsis flower specific defense gene expression patterns affect resistance to pathogens
}

\author{
Luisa Ederli ${ }^{1+}$, Adam Dawe ${ }^{2+}$, Stefania Pasqualini ${ }^{1}$, Mara Quaglia ${ }^{3}$, Liming Xiong ${ }^{2}$ and Chris Gehring ${ }^{2 *}$ \\ ${ }^{1}$ Department of Chemistry, Biology and Biotechnology, University of Perugia, Perugia, Italy \\ 2 Division of Biological and Environmental Sciences and Engineering, King Abdullah University of Science and Technology, Thuwal, Saudi Arabia \\ ${ }^{3}$ Department of Agricultural, Food and Environmental Sciences, University of Perugia, Perugia, Italy
}

\section{Edited by:}

Sonia Osorio, Málaga University,

Spain

Reviewed by:

Stefanie Wienkoop, University of

Vienna, Austria

Asdrubal Burgos, Max Planck

Institute for Molecular Plant

Physiology, Germany

*Correspondence:

Chris Gehring, Division of Biological and Environmental Sciences and

Engineering, King Abdullah

University of Science and

Technology, Thuwal 23955-6900,

Saudi Arabia

e-mail: christoph.gehring@

kaust.edu.sa

${ }^{t}$ These authors have contributed equally to this work.
We investigated whether the Arabidopsis flower evolved protective measures to increase reproductive success. Firstly, analyses of available transcriptome data show that the most highly expressed transcripts in the closed sepal (stage 12) are enriched in genes with roles in responses to chemical stimuli and cellular metabolic processes. At stage 15, there is enrichment in transcripts with a role in responses to biotic stimuli. Comparative analyses between the sepal and petal in the open flower mark an over-representation of transcripts with a role in responses to stress and catalytic activity. Secondly, the content of the biotic defense-associated phytohormone salicylic acid (SA) in sepals and petals is significantly higher than in leaves. To understand whether the high levels of stress responsive transcripts and the higher SA content affect defense, wild-type plants (Col-0) and transgenic plants defective in SA accumulation (nahG) were challenged with the biotrophic fungus Golovinomyces cichoracearum, the causal agent of powdery mildew, and the necrotrophic fungus Botrytis cinerea. NahG leaves were more sensitive than those of Col-0, suggesting that in leaves SA has a role in the defense against biotrophs. In contrast, sepals and petals of both genotypes were resistant to G. cichoracearum, indicating that in the flower, resistance to the biotrophic pathogen is not critically dependent on SA, but likely dependent on the up-regulation of stress-responsive genes. Since sepals and petals of both genotypes are equally susceptible to $B$. cinerea, we conclude that neither stress-response genes nor increased SA accumulation offers protection against the necrotrophic pathogen. These results are interpreted in the light of the distinctive role of the flower and we propose that in the early stages, the sepal may act as a chemical defense barrier of the developing reproductive structures against biotrophic pathogens.

Keywords: Arabidopsis thaliana, flower, sepal, petal, host defense, biotrophic pathogen, salicylic acid

\section{INTRODUCTION}

Successful plant sexual reproduction relies on many factors including optimal time of flowering. Consequently, mechanisms have evolved that integrate environmental signals such as light and temperature, with endogenous developmental signals such as autonomous and gibberellin-dependent pathways to regulate flowering time (Simpson and Dean, 2002). However, plants exposed to adverse environmental conditions can activate the flowering program prematurely. Stress factors that are able to promote flowering include pathogen attacks, high levels of ultraviolet light, poor nutrition and drought stresses (Martinez et al., 2004; Kolar and Senkova, 2008; Riboni et al., 2013). It has also been reported that salicylic acid (SA) regulates flowering in Arabidopsis, likely acting as a link between stress responses

Abbreviations: SA, salicylic acid; nah $G$, salicylate hydroxylase; SAGT, SA glucosyltransferase; GO, gene ontology; RCS, response to chemical stimulus; CMP, cellular metabolic process; RBS, response to biotic stimulus; RCS, response to chemical stimulus; ROO, response to other organisms; LRRK, leucine-rich receptor kinase; GA, gibberellic acid; dpi, days post-inoculation. and the regulation of reproductive development (Martinez et al., 2004). SA-mediated floral promotion appears to be regulated through sumoylation and involves chromatin modifications (Jin et al., 2008). Indeed, SA-dependent regulation of chromatin modification through histone replacement mechanisms may be responsible for maintaining a concomitant repressive state of both systemic acquired resistance to pathogens and transition to flowering in Arabidopsis (March-Diaz et al., 2008). However, the molecular mechanisms of SA-dependent flowering induction remain elusive and little attention has been given to the accumulation of SA in floral organs nor indeed to the function of elevated SA levels, e.g., in the response to microbial pathogens (e.g., Thomma et al., 1998; Noutoshi et al., 2012).

Given that the flower is the organ of sexual reproduction, it is reasonable to expect that this organ has evolved effective morphological structures and mechanisms to protect itself from pathogens. There is growing interest in morphological structures, compounds and mechanisms of biotic defense of the flower (e.g., Rodrigues Marques et al., 2014). However, despite the fact that 
work in the Arabidopsis model system does offer the obvious advantages of access to a complete genome and transcriptome data as well as a large mutant collection, defense studies in Arabidopsis flowers have remained scarce, not least because of the comparatively small organ size.

It is somewhat surprising that hardly any attention has been given to the role of the sepal in the defense of plants against pathogens. Exceptions are an early report that states that in tobacco a pathogenesis-related protein (PR-1) accumulates in the sepal (Lotan et al., 1989), and more recently, PR-5 promoter activity was observed in tobacco sepal tips (Kenton et al., 2000). There is no report in the literature that would suggest a role of the sepal in the defense against pathogens and this may well be due to the small size of the floral tissue which in the past has limited molecular and biochemical analyses.

In Arabidopsis thaliana the sepals are modified green leaf-like organs that enclose the developing flower. They form the outermost whorl - the calyx - of the flower. Early flower development is divided into 12 stages beginning with the initiation of a floral buttress on the flank of the apical meristem (stage 1) and ending with the rapid extension of the petals to the height of the medial stamen (stage 12) (Smyth et al., 1990). The sepal primordia arise in stage 3 and outgrow the flower primordium (stage 4). Petal and stamen primordia appear at stage 5 and end up completely enclosed by the sepals (Smyth et al., 1990). The Arabidopsis flower organs are arranged in concentric whorls as four sepals, four petals, six stamens and two fused carpels (Bossinger and Smyth, 1996). A distinct feature of the sepals is that they contain cells of vastly different sizes, notably the polyploid giant pavement cells that have arisen through endo-reduplication (Roeder et al., 2010), performing karyokinesis but not cytokinesis. While the function of these pavement cells remains unclear, it has been speculated that they may play a role in the defense against insect predators, prevent water stress, and improve the mechanical properties of the organ (Traas et al., 1998), albeit by unspecified mechanisms.

Here we make use of the Arabidopsis model system to perform a comparative system analysis (Meier and Gehring, 2008; Meier et al., 2010) of the sepal and petal transcriptome with a view to gain insight into aspects of organ specific defense responses against pathogen attack. In addition, we also measure SA in the flower and describe responses of the flower to both biotroph and necrotroph pathogens. Finally, we propose that the sepal with its specific morphological characteristics functions not only as a mechanical but also (bio-)chemical defense shield for the developing reproductive organs.

\section{MATERIALS AND METHODS PLANT MATERIAL}

Arabidopsis thaliana L. Heynh. wild-type Columbia (Col-0) and transgenic nahG plant which is defective in the SA accumulation (Lawton et al., 1995) were used in this study. Seeds were surface-sterilized first in $70 \%(\mathrm{v} / \mathrm{v})$ ethanol and then in $7 \%(\mathrm{v} / \mathrm{v})$ sodium hypochlorite with $0.2 \%(\mathrm{w} / \mathrm{v})$ Triton $\mathrm{X}-100$ for $8 \mathrm{~min}$ at room temperature under a sterile laminar flow hood. Seeds were rinsed three times with sterile distilled water and re-suspended in $500 \mu \mathrm{L}$ sterile distilled water. Plants were grown in soil (Patzer
Einheitserde, Manna Italia, Bolzano, Italy) in $10 \mathrm{~cm}$ pots in a growth chamber with a 14-h photoperiod, a photosynthetic photon fluence rate of $120 \mu \mathrm{mol} \mathrm{m}{ }^{-2} \mathrm{~s}^{-1}$, day/night air temperatures of $22^{\circ} \mathrm{C} / 20^{\circ} \mathrm{C}$, and a relative humidity of $60-75 \%$. The plants were watered by sub-irrigation. All seeds were treated at $4^{\circ} \mathrm{C}$ for 2 days before moving to the growth environment. For all analyses leaves were sampled from 4 week old plants, whereas sepals and petals were taken from completely open flowers corresponding to development stage 14-15 (Smyth et al., 1990) of 6-7 week old plants.

\section{SCANNING ELECTRON MICROSCOPY}

Plant samples from whole soil grown plants were detached with a dissecting knife and immediately placed on a $6 \mathrm{~mm}$-wide double adhesive and conductive tape (Canemco Inc., Quebec, Canada) that was pre-attached onto the specimen stage. The specimen was examined with a bench-top scanning electronic microscope (NeoScope JCM-5000, Jeol Ltd, Tokyo, Japan) and images were acquired using the software provided by the manufacturer.

\section{FREE AND TOTAL SA EXTRACTION AND QUANTIFICATION}

For SA quantification, four fully expanded leaves were harvested from 9 individual 4 week old plants of two independent cultivations. Sepal and petal SA quantification was carried out twice, sampling $4 \mathrm{mg}$ for each replicate (approximately 80 sepals or petals). Plant material was quick-frozen with liquid nitrogen and stored at $-80^{\circ} \mathrm{C}$ until processed for SA quantification and fungal DNA quantification. To perform SA extraction and quantification, leaf (500 mg FW) and sepal or petal ( $4 \mathrm{mg} \mathrm{FW}$ ) samples were pulverized under liquid $\mathrm{N}_{2}$ and homogenized in a mortar with $1.5 \mathrm{~mL} \mathrm{90 \%} \mathrm{(v/v)} \mathrm{methanol} \mathrm{in} \mathrm{water.} \mathrm{The} \mathrm{homogenate} \mathrm{was} \mathrm{cen-}$ trifuged at $11,000 \mathrm{~g}$ for $5 \mathrm{~min}$ and the extraction repeated with $0.5 \mathrm{~mL} 100 \%$ methanol. The recovery was evaluated by adding $2.5 \mu \mathrm{L}$ of $o$-anisic acid $\left(10 \mathrm{mg} \mathrm{mL}^{-1}\right)$ as internal standard in the first extraction mixture. All the data were corrected for SA recovery, which ranged from 85 to $100 \%$. After the two extractions the supernatants were combined and the methanol: water mixtures were evaporated in a speed vacuum concentrator with heat $\left(40^{\circ} \mathrm{C}\right)$ (Heto, Heto-Holten, Gydevang, Denmark). To avoid sublimation of SA during solvent evaporation $0.2 \mathrm{M}$ sodium hydroxide was added to combined supernatants before concentration. The residue was resuspended in $1 \mathrm{~mL}$ of $5 \%$ trichloroacetic acid (TCA), mixed by vortex for $10 \mathrm{~min}$, and divided into two $0.5 \mathrm{~mL}$ aliquots. One aliquot was passed through $0.2 \mu \mathrm{m}$ Millipore filters; then, the sample was partitioned with $1 \mathrm{~mL}$ of a $1: 1(\mathrm{vol} / \mathrm{vol})$ mixture of ethyl acetate/cyclopentane containing 1\% (vol/vol) isopropanol. The uppermost organic phase containing the free SA was then dried by using speed vacuum concentrator. The dried extract was suspended in $0.2 \mathrm{~mL}$ of the HPLC mobile phase [methanol: 2\% aqueous acetic acid, 45:55 (v/v)] and free SA content was quantified by HPLC. The amount of total SA was quantified as follows: the TCA re-suspended aliquot after filtration through $0.2 \mu \mathrm{m}$ Millipore filters was added to $1.25 \mathrm{~mL}$ of $8 \mathrm{M} \mathrm{HCl}$ and hydrolyzed for $1 \mathrm{~h}$ at $90^{\circ} \mathrm{C}$ to release SA from any acid-labile conjugated forms. The released free SA was then partitioned with $3.25 \mathrm{~mL}$ of a $1: 1(\mathrm{vol} / \mathrm{vol})$ mixture of ethyl acetate/cyclopentane containing $1 \%$ ( $\mathrm{vol} / \mathrm{vol}$ ) isopropanol. The 
top organic phase was dried by using speed vacuum concentrator, resuspended in $0.2 \mathrm{~mL}$ of the HPLC mobile phase and analyzed by HPLC. Analysis of free SA was performed in HPLC (Jasco, Tokyo, Japan) by using a $5 \mu \mathrm{m}$ C18 column (Luna, $150 \mathrm{~mm} \times 4.6 \mathrm{~mm}$; Phenomenex, Inc., Torrance, CA) with isocratic elution. The SA quantification was obtained with a spectrofluorescence detector (Jasco, Tokyo, Japan) using $\mathrm{Ex}=209 \mathrm{~nm}$ and $\mathrm{Em}=402 \mathrm{~nm}$ and SA concentrations were calculated using a linear range of calibration standards from 0 to $100 \mathrm{ng}$ SA.

\section{GOLOVINOMYCES CICHORACEARUM INOCULATION}

The inoculum of Golovinomyces cichoracearum (D.C.) V.P. Heluta (formerly Erysiphe cichoracearum D.C.) (Quaglia et al., 2012) were maintained on tobacco plants cv Havana 425 and refreshed on new tobacco plants 10 days before use for Arabidopsis inoculation. Conidia were harvested from tobacco plants by irrigation with sterile deionized water added with $0.04 \%(\mathrm{v} / \mathrm{v})$ of the surfactant Tween ${ }^{\circledR} 20[10 \%(\mathrm{v} / \mathrm{v})$ aqueous solution, Boehringer Mannheim, Germany]. The inoculum concentration was measured by hemocytometer and adjusted to $1 \times 10^{6}$ conidia $\mathrm{mL}^{-1}$. For leaf inoculation, 4 week old Arabidopsis plants were sprayed with the conidial suspension using a hand atomizer until runoff. Floral spray inoculation was carried out in the same manner on the whole attached inflorescence from 6 to 7 week old Arabidopsis plants. In addition, we also sprayed detached rosette leaves from 4 week old Arabidopsis plants and sepals and petals taken from flowers at stages 14 and 15 (Smyth et al., 1990). All samples were placed in Petri dishes $(9 \mathrm{~cm}$ diameter) containing $1.2 \%$ sterilized water-agar (WA). Plants and plates were incubated in the growth chamber under the conditions described above. The spray inoculation technique allowed to obtain comparable numbers of conidia per area on the surface of the three organs $\left(0.42 \pm 0.06\right.$ conidia $\mathrm{mm}^{-2}$ on the leaves, $0.40 \pm 0.08$ conidia $\mathrm{mm}^{-2}$ on the sepals, $0.39 \pm 0.1$ conidia $\mathrm{mm}^{-2}$ on the petals). Two independent experiments were performed. Leaves, sepals and petals from both plants and plates were taken after 2 and 4 days post-inoculation (dpi) for evaluation of fungal growth. Moreover, macroscopic disease symptoms were evaluated at 7 dpi.

\section{GOLOVINOMYCES CICHORACEARUM GROWTH ASSESSMENT BY LIGHT MICROSCOPY AND GENOMIC DNA OUANTIFICATION}

Visualization of G. cichoracearum structures (mycelia, conidiophores and conidia) in all inoculated samples was carried out under the light microscope after Trypan blue staining (Reuber et al., 1998). Briefly, leaves and sepals were immersed in $96 \%(\mathrm{v} / \mathrm{v})$ ethanol and placed in a $60^{\circ} \mathrm{C}$ water bath for $15 \mathrm{~min}$ to clear the chlorophyll, then gently rinsed for 5 min with deionized water. Petals, cleared leaves and sepals were stained directly on microscope slides with Trypan blue solution [0.01\% Trypan blue (v/v) in lactic acid: phenols: glycerol: water (1:1:1:1 v/v)]. Stained samples were observed using a Carl Zeiss (Jena, Germany) microscope at $5 \mathrm{X}$ magnification. On sepals and petals, fungal colonies were analyzed on the entire organ surface while the central portion of the outer leaf surface (three randomly selected areas of $5.3 \mathrm{~mm}^{2}$ each) was chosen for analysis. The total number of colonies, and conidiophores per colony and conidia per colony were counted.
Data were subject to one-way (genotype) analysis of variance (ANOVA). The means were compared using Duncan's multiple range test at the $1 \%$ significance level.

Genomic DNA from Arabidopsis leaves and sepals was isolated from Col-0 and nahG plants spray-inoculated with G. cichoracearum at 2 and 4 dpi using NucleoSpin ${ }^{\circledR}$ Plant II kits (Macherey-Nagel, Düren, Germany) according to the manufacturer instructions. Plant and fungal biomass content in the DNA extracts was determined by independent semi-quantitative PCR analysis where the reaction mixtures contained the primer pair designed for the Arabidopsis gene AT5G19510 (elongation factor; forward 5' -TGATGTCAAGGTTTACGCTG-3' and reverse 5' ACTCTCTTTAGGCTTCTTGG-3' ${ }^{\prime}$ ), or primer sequences specific for $G$. cichoracearum were derived from the ribosomal ITS region of the fungus (forward 5'-GGTTGTGTCCGCCAGAGACC-3 and reverse $5^{\prime}$-TGATGTCAAGGTTTACGCTG-3) as reported elsewhere (Chen et al., 2008). Cycling parameters were as follows: initial denaturation at $94^{\circ} \mathrm{C}$ for $2 \mathrm{~min}$, followed by 28 cycles of $1 \mathrm{~min}$ at $94^{\circ} \mathrm{C}, 1 \mathrm{~min}$ at $58^{\circ} \mathrm{C}, 1.5 \mathrm{~min}$ at $72^{\circ} \mathrm{C}$, and final extension at $72^{\circ} \mathrm{C}$ for $5 \mathrm{~min}$. Serial dilutions of pure genomic DNA from G. cichoracearum and Arabidopsis were used to trace a calibration curve that was used to quantify plant and fungal DNA in each sample. Results are presented as a ratio between fungal and plant DNA in the leaf and sepal. Each data point represents the mean of two independent biological samples.

\section{BOTRYTIS CINEREA INOCULATION AND LESION EVALUATION}

An isolate of Botrytis cinerea Pers. ex Fr. (Quaglia et al., 2011) was used essentially as described elsewhere (Muckenschnabel et al., 2002), conidia were harvested by irrigation with a sterile aqueous solution of $10 \mathrm{mM}$ sucrose and $10 \mathrm{mM} \mathrm{KH}_{2} \mathrm{PO}_{4}$ added with $0.04 \%(\mathrm{v} / \mathrm{v})$ of the surfactant Tween ${ }^{\circledR} 20$ from 10 days old colonies grown on Potato Dextrose Agar, at $21 \pm 2{ }^{\circ} \mathrm{C}$, in the dark. The spore suspension was passed through two layers of cheese cloth and, after counting the numbers of spores with a hemocytometer, adjusted to the final concentration of $1 \times 10^{5}$ conidia $\mathrm{mL}^{-1}$. Inoculation with $5 \mathrm{~mL}$ of conidia in suspension was performed by spraying the conidia until run-off on 4 week old leaves or inflorescences of 6-7 week old Arabidopsis plants. This was performed on detached plant organs placed in Petri dishes $(9 \mathrm{~cm}$ diameter) containing 1.2\% WA. The plates were incubated in the growth chamber at the conditions described above and the high humidity was maintained by covering the plastic lid. Sprayinoculated plants were observed at 2 and 7 dpi for qualitative evaluation of the infection. On drop-inoculated detached leaves necrotic lesions area was determined at 3 dpi (Ferrari et al., 2007) and data were subject to one-way (genotype) analysis of variance (ANOVA). The means were compared using Duncan's multiple range test, at the $1 \%$ significance level.

\section{TRANSCRIPTOMICS ANALYSES}

Analyses were performed on sepal data (Voelckel et al., 2010) and publicly available microarray data from the AtGenExpress developmental series (Schmid et al., 2005) for flowers and pollen (GSE5632) and leaves (GSE5630) for sepal (stage 15, GSM131603-GSM131605), petal (stage 15, GSM131606-GSM131608), rosette (GSM131510-GSM131512), 
leaf $1+2$ GSM131498-GSM131500) and senescent leaf (GSM131537-GSM131539) samples were downloaded from Gene Expression Omnibus (GEO, http://www.ncbi.nlm.nih. gov/geo/, Edgar et al., 2002; Barrett et al., 2011). Arrays were normalized using Robust Multi-Array Averaging (RMA) in the Bioconductor affylmGUI package (Smyth, 2004; Smyth et al., 2005; Wettenhall et al., 2006) before a linear fit model was applied and the following contrasts (differentials) calculated: sepal vs. petal, sepal vs. rosette, sepal vs. leaf (not shown), sepal vs. senescent leaf, petal vs. senescent leaf. The top 25 most up-regulated genes in each contrast were then selected according to descending B-statistics. GO analyses were performed on each up-regulated gene list using AgriGO (http://bioinfo.cau.edu. cn/agriGO/, Du et al., 2010). The data from the transcriptional analyses are in Table S1.

\section{RESULTS}

\section{MORPHOLOGICAL CHARACTERISTICS OF THE ARABIDOPSIS THALIANA SEPAL}

In Arabidopsis the sepals are green leaves, not dissimilar to upper shoot vegetative leaves, that enclose the developing reproductive organs. Scanning electron microscopy reveals that in the young developing buds, prior to the emergence of the petals, the leaves are bent and the upper edges are overlapping and appear tightly sealed (Figure 1A) effectively completely enclosing the reproductive organs. The pavement cells of the sepal show a degree of interdigitation (Figure 1B, inset), albeit less pronounced than in mature vegetative leaf cells. Separated by rows of $\geq 2$ pavement cells of "normal" size, we find highly elongated giant cells with hardly any interdigitation typical for leaf epidermal cells (Staff et al., 2012). The sepal is also characterized by a high number of stomata $\left(\geq 3 / 100 \mu \mathrm{m}^{2}\right)$ on the upper surface, which is directly exposed to the atmosphere, indicating high metabolic activity but also vulnerability to pathogens that can enter through the stomata (Melotto et al., 2008; Zhang et al., 2008) and may do so by forcing stomata open (Gottig et al., 2008). Bud burst is characterized by the breaking of the sepal seal and emergence of the petals (Figure 1B). The latter show small cells that are more elongated at the base and more globular at the tip of the growth axis and do not contain stomata. By this stage, the sepal seems to have largely lost the mechanical protective function and we note a loss of turgor and a decrease in cellular organization indicative for the onset of senescence (Warner et al., 2000).

\section{INFERENCES FROM THE SEPAL TRANSCRIPTOME}

In order to gain insight into the functions of the sepal, a systems level analysis of transcriptional data from different stages was undertaken (Meier et al., 2008, 2010; Meier and Gehring, 2008). Of the 25 most abundant transcripts at stage 12 (Table 1), a significant enrichment of genes in the gene ontology (GO) categories "Response to chemical stimulus" (RCS) and "Cellular metabolic process" (CMP) was noted. Furthermore, the SA UDPglucosyltransferase (AT2G43820) involved in the formation of SA 2 -O- $\beta$-glucoside (SAG) and its glucose ester (SGE) is one of the 10 most expressed genes at this stage. Dramatic increases in both these conjugates are considered a hallmark of the biotic defense program.

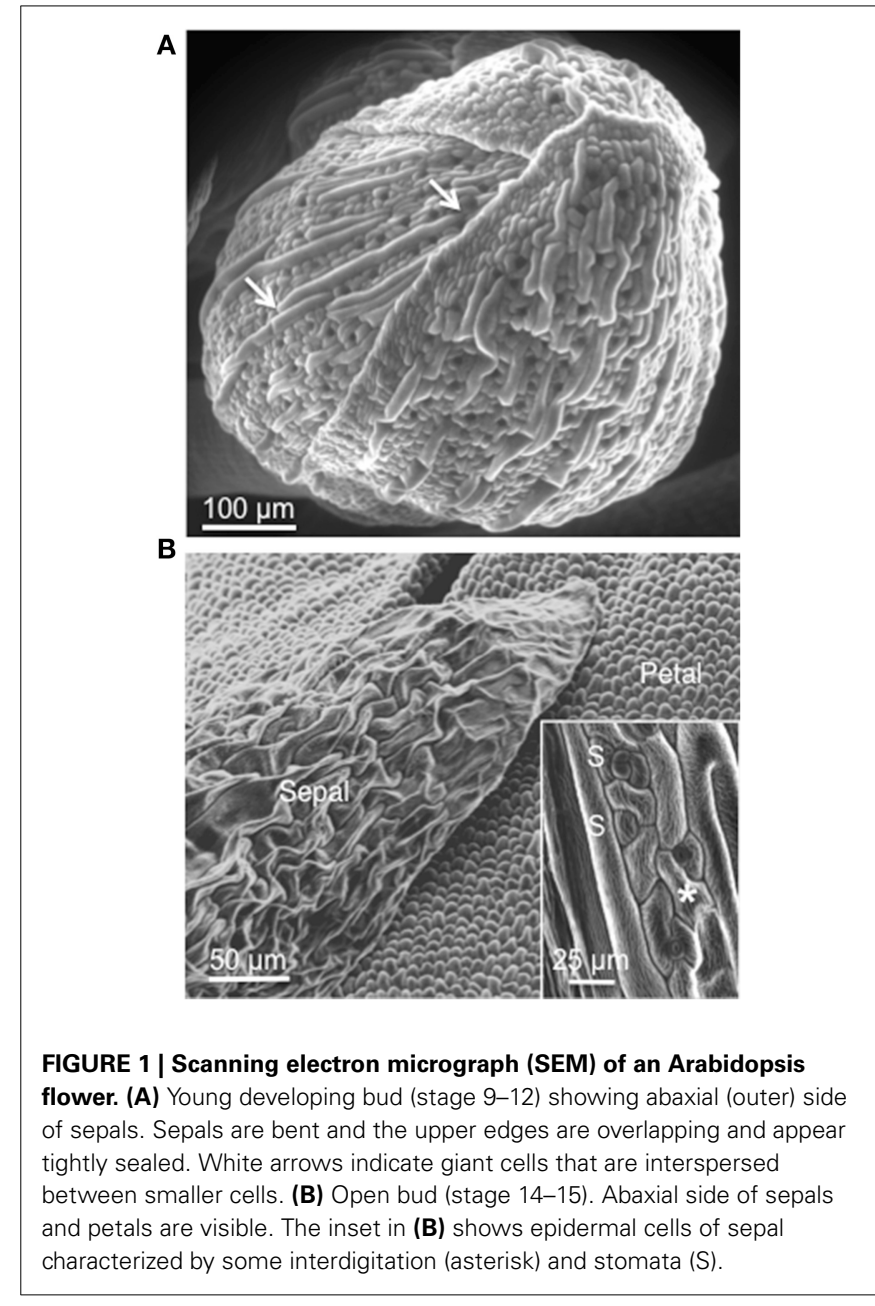

At stage 15 when the stigma extends above the anthers, we find that the 25 most highly expressed genes (Table 2 ) are enriched in the categories "Response to biotic stimulus" (RBS), "Response to chemical stimulus" (RCS), and "Response to other organisms" (ROO) and nine of the most highly expressed genes encode proteins that occur in the extracellular space. The functional enrichment is even more pronounced in the 10 most expressed genes (Table 2), with half of the encoded proteins being targeted to the extracellular space and three directly involved in biotic stress responses (GO:0009607). One of the genes not directly involved in stress responses is the Agamous-like 16 MADS-box encoding gene that is expressed in leaf, root and stem, with higher RNA accumulation in guard cells and trichomes. This protein is believed to have a role in stomatal lineage progression and stomatal development (Kutter et al., 2007) and is induced in response to $\mathrm{ABA}$ and by pathogens.

Another of the highly expressed genes encodes a leucine-rich receptor kinase (LRRK; AT1G35710). If we do a GO analysis on the top 25 expression correlated genes $(r>0.85)$ with AT1G35710, we observe that they are highly significantly enriched in the categories "Defense response" (GO:0006952; FDR = $9.8 \mathrm{e}^{-08}$ ) and "Response to salicylic acid stimulus" (GO: 0009751; $\left.\mathrm{FDR}=7.6 \mathrm{e}^{-06}\right)$. From this we inferred that the protein is 
Table 1 | Most expressed sepal genes at stage 12.

\begin{tabular}{|c|c|c|}
\hline Gene ID & GO cat. & Annotation \\
\hline AT4G25100 & RCS CMP & Superoxide dismutase \\
\hline AT3G62380 & & Hypothetical protein \\
\hline AT1G05680 & & UDP-glucosyltransferase, acts on IBA \\
\hline AT2G25510 & & Expressed protein \\
\hline AT2G21220 & $\mathrm{RCS}$ & Auxin-responsive protein \\
\hline AT5G43450 & & 2-Oxoglutarate-dependent dioxygenase \\
\hline AT5G14740 & & Carbonic anhydrase 2 \\
\hline AT5G24150 & & Squalene monooxygenase 11 \\
\hline AT2G43820 & * & SA UDPglucosyltransferase-SAGT (SA $\downarrow$ ) \\
\hline AT1G05560 & RCS CMP & UDP-gluc. transfer. 1 (ABA) \\
\hline AT5G22300 & RCS CMP & Nitrilase 4 (NIT4) \\
\hline AT4G26530 & CMP & Fructose-bisphosphate aldolase \\
\hline AT1G14150 & CMP & $\mathrm{O}_{2}$ evolving enhancer 3 \\
\hline AT3G28220 & & Meprin and TRAF homol. domain protein \\
\hline AT2G41090 & & CAM-like binding protein \\
\hline AT4G17340 & & MIP family protein, TIP2;2 \\
\hline AT5G58770 & CMP & Dehydrodolichyl diphosphatase synthase \\
\hline AT3G14630 & & Cytochrome P450 putative \\
\hline AT1G23130 & & Bet $v$ I allergen \\
\hline AT3G22340 & & Copia-like retro-transposon \\
\hline AT1G59870 & RCS CMP & $\mathrm{ABC}$ transporter protein, $\mathrm{ABCG} 36$ \\
\hline AT3G03480 & CMP & Acetyl CoA:(Z)-3-hexen-1-ol acetyl transf. \\
\hline AT3G57230 & CMP & MADS-box protein \\
\hline AT3G01290 & & Band 7 family protein \\
\hline AT4G23600 & RCS CMP & Coronatine-ind., JA and ABA resp. Cys lyase \\
\hline
\end{tabular}

involved in responses against pathogen defense and this is again entirely consistent with its stimulus specific expression profile (Zimmermann et al., 2004).

Furthermore, a gene encoding a Band 7 family protein that is involved in $\mathrm{N}$-terminal myristoylation, the modification of a protein with a hydrophobic 14-carbon fatty acid myristate that enables membrane attachment of soluble proteins, protein targeting and interactions and partitioning into specific membrane domains (Sorek et al., 2009) is also highly expressed. This is relevant since post-translational protein modifications including myristoylation have a role in pathogen-induced defense signaling (Stulemeijer and Joosten, 2008) and can both specifically activate (Nimchuk et al., 2000; Shan et al., 2000) or repress (Andriotis and Rathjen, 2006) defense signaling components.

Also in the group of the 10 most abundant sepal transcripts is AtPNP-A (AT2G18660) that encodes a Plant Natriuretic Peptide with a role in both responses to pathogens (Gottig et al., 2008; Meier et al., 2008) as well as photosynthesis and the regulation of cellular homeostasis (Garavaglia et al., 2010; de Jonge et al., 2012). In addition, both a chitinase (AT2G43570) and an aspartyl protease family protein (AT5G10760) are annotated as targeted to the extracellular space where they are likely to act in the chemical defense against pathogens.

Another abundant transcript encodes a nitrilase (NIT4; AT5G22300) that acts on C-N bonds (but not peptide bonds).
Table 2 | Most expressed sepal genes at stage 15.

\begin{tabular}{|c|c|c|}
\hline Gene ID & GO cat. & Annotation \\
\hline AT2G43570 & \# & Chitinase \\
\hline AT2G14610 & \# RBS RCS ROO & Pathogenesis-related protein 1 (PR-1) \\
\hline AT3G57230 & & MADS-box protein (AGL16) \\
\hline AT4G25100 & $\mathrm{RCS}$ & Superoxide dismutase [Fe]chloroplast \\
\hline AT1G75040 & \# RBS ROO & Pathogenesis-related protein 5 (PR-5) \\
\hline AT2G14560 & RBS RCS ROO & Coronatine-induced protein \\
\hline AT4G23600 & \# RCS & $\begin{array}{l}\text { Coronatine-ind., JA and ABA res. Cys } \\
\text { lyase }\end{array}$ \\
\hline AT1G35710 & & $\begin{array}{l}\text { Leucine-rich repeat transmembrane } \\
\text { kinase (LRRK) }\end{array}$ \\
\hline AT2G18660 & \# & Plant Natriuretic Peptide (AtPNP-A) \\
\hline AT3G01290 & & Band 7 family protein, myristoylation \\
\hline AT4G11650 & \# RBS ROO & $\begin{array}{l}\text { Osmotin-like protein (OSM34), biotic } \\
\text { defense }\end{array}$ \\
\hline AT5G10760 & \# & Aspartyl protease family protein \\
\hline AT2G43820 & * & $\begin{array}{l}\text { SA UDPglucosyltransferase_SAGT } \\
(\text { SA } \downarrow)\end{array}$ \\
\hline AT5G22300 & $\mathrm{RCS}$ & Nitrilase 4 (NIT4) \\
\hline AT3G60390 & & $\begin{array}{l}\text { Homeobox-leucine zipper protein } 3 \\
\text { (HAT3) }\end{array}$ \\
\hline AT3G50420 & & Pentatricopeptide (PPR) repeat protein \\
\hline AT4G14365 & & $\begin{array}{l}\text { Zinc finger/ankyrin repeat family } \\
\text { protein }\end{array}$ \\
\hline AT1G61800 & RBS RCS ROO & $\begin{array}{l}\text { Glucose-6-phosphate/phosphate } \\
\text { translocator }\end{array}$ \\
\hline AT1G21250 & \# RCS & Wall-associated kinase 1 (WAK1) \\
\hline AT3G22550 & & Senescence-associated protein \\
\hline AT1G20070 & & Expressed chloroplast protein \\
\hline AT5G23010 & & 2-Isopropylmalate synthase 3 (IMS3) \\
\hline AT2G44240 & \# RCS & Oxidative stress response protein \\
\hline AT4G37370 & & Cytochrome P450 putative \\
\hline AT3G28500 & & $\begin{array}{l}\text { 60S Acidic ribosomal protein P2 } \\
\text { (RPP2C) }\end{array}$ \\
\hline
\end{tabular}

RBS, Response to biotic stimulus (GO: 0009607, FDR: 0.0009); RCS, Response to chemical stimulus (GO: 0042221, FDR: 0.0009); ROO, Response to other organisms (GO: 0051707, FDR: 0.0009); * Salicylic acid response; \# Proteins directed to the extracellular region, apoplast.

The NIT4 expression profile appears to be highly developmentand organ-specific, suggesting a critical role in the sepal. Expression is strongly down-regulated in response to methyljasmonate and strongly induced by Pseudomonas parasitica and Pseudomonas syringae, but not in penta mutants (loss-of-function in the gibberellic acid (GA) mutants GAI, RGA, RGL1, and RGL2, four DELLA genes) where expression is suppressed. The expression data would therefore support the idea that GA can signal through jasmonates in flower development (Cheng et al., 2009).

In a next step we analyzed the promoters of the highly expressed genes in the sepal. In the top 10 (stage 15) we find a significant enrichment $\left(P<10^{-4}\right)$ of the LS7 element (ACGTCATAGA). The cis-element is found in the promoter of the $P R-1$ gene and in the coronatine-induced gene (Table 2). Previously the promoter of $P R-1$ has been reported to contain two putative TGA transcription factor-binding targets termed 
linker scan7 (LS7) and LS5 (Lebel et al., 1998), the former acting as positive regulator of $P R-1$ expression in response to 2,6dichloroisonicotinic acid and SA. The TGA transcription factors regulate expression of $P R$ genes through their interaction with the positive regulator NPR1 (non-expresser of $P R-1$ ). In particular, $P R-1$ expression was reported to be dependent on TGA factor recruitment to the LS7-containing $P R-1$ promoter in an SA- and NPR1-dependent manner (Johnson et al., 2003).

If we expand the promoter content analyses to the 100 most highly expressed sepal genes, we find significant enrichments for the I-box motif $\left(P<10^{-4}\right)$ and the W-box motif (TTGACC or TTGACT; $P<10^{-4}$ ) that is the target site for WRKY transcription factors which in turn have been implicated in the regulation of transcriptional re-programming associated with plant immune responses (Eulgem and Somssich, 2007). NPR1 expression is important for the activation of plant defense responses and WRKY encoding genes act upstream of NPR1 and promote its expression during the activation of plant defense responses, a mechanism entirely consistent with SA-induced expression of WRKY (Yu et al., 2001). In addition, it was noted that five WRKYs (AT2G30250, AT4G01720, AT2G23320, AT5G07100, and AT4G31550) are positively expression correlated $(r>0.65)$ with the Band 7 family protein that has a role in myristoylation which in turn is implicated in pathogen-induced defense signaling (Stulemeijer and Joosten, 2008).

Since pathogen defense is likely to be an essential function of the sepals, we were interested to see the induction profile of the isochorismate synthase (ICS) gene (AT1G74710) that is a key gene for SA biosynthesis in Arabidopsis. Between stages 12 and 15 it increased $>1.5$-fold. Remarkably, one of the highly expressed genes at the stages 12 and 15 encodes a SA UDPglucosyltransferase (AT2G43820) that inhibits the accumulation of SA (Tables 1, 2). Recently, it has been demonstrated that activators of defense that inhibit SA glucosyltransferases (SAGTs) can indeed augment the pool of free SA and thus enhance plant resistance to pathogens (Noutoshi et al., 2012). It would therefore appear that the synthesis of SA is not only enhanced in the sepal but also very tightly controlled.

\section{THE SEPAL, PETAL, AND ROSETTE LEAF HAVE SPECIFIC TRANSCRIPTOMIC SIGNATURES}

In order to gain further insight into unique sepal functions, we have undertaken to identify transcripts that are differentially expressed in the sepal as compared to the petal and/or rosette leaves. The comparison between the highly up-regulated genes in the sepal as compared to the petal revealed that in this group the top 25 differentially expressed genes are enriched in the categories "Response to stress" and "Catalytic activity" (Table 3 and Table S1). This is consistent with a specialized role in defense and in chemical defense in particular given that the latter depends heavily on catalytic activity essential for the production of flavonoids, phenolics, glucosinolates, terpenoids, and alkaloids (Kliebenstein, 2012). When the highly expressed sepal genes were compared to the rosette leaf transcriptome, a significant enrichment for proteins with a role in catalysis was observed (Table 4 and Table S1). Again, enhanced catalytic activity is an indication of chemical defense. Since the senescence response shares some
Table 3 | Genes highly up-regulated at stage 15 sepals vs. petals.

\begin{tabular}{|c|c|c|}
\hline Gene ID & GO cat. & Annotation \\
\hline AT4G17030 & & EG45-like domain containing protein 2 \\
\hline AT4G25100 & RS CA & Superoxide dismutase [Fe] \\
\hline AT1G02920 & CA & Glutathione S-transferase 11 \\
\hline AT4G23600 & RS CA & Coronatine-induced, JA and ABA responsive \\
\hline AT1G19580 & CA & Carbonic anhydrase, chloroplastic \\
\hline AT2G43570 & CA & Chitin-binding, chitinase activity \\
\hline AT3G13790 & RS CA & $\beta$-Fructofuranosidase, insoluble isoenz. \\
\hline AT4G23150 & CA & Cysteine-rich receptor-like protein kinase 7 \\
\hline AT2G02930 & CA & Glutathione S-transferase 16 \\
\hline AT2G37770 & CA & NADPH-dependent aldo-keto reductase \\
\hline AT1G75040 & RS & Pathogenesis-related protein 5 (PR-5) \\
\hline AT3G23110 & RS CA & Receptor-like protein 37 , defense response \\
\hline AT5G19440 & & Alcohol dehydrogenase, NAD activity \\
\hline AT1G52200 & RS & Divalent metal ion transport \\
\hline AT3G51600 & & Lipid transfer protein (PR-14) family \\
\hline AT3G23570 & CA & $\alpha / \beta$-Hydrolases superfamily protein, salt resp. \\
\hline AT3G01290 & & Defense response to fungus \\
\hline AT2G05380 & & Glycine-rich protein 3 \\
\hline AT4G14365 & & XB3 ortholog 4, defense (zinc-finger protein) \\
\hline AT5G23010 & CA & 2-Isopropylmalate synthase 3 (MAM1) \\
\hline AT1G13080 & RS & Cytochrome P450 71B15 \\
\hline AT3G57260 & RS CA & $\beta$ 1,3-Glucanase \\
\hline AT3G22600 & & Lipid-transfer protein \\
\hline AT5G44580 & & Regulator of defense response (SAR) \\
\hline AT2G26440 & CA & Pectinesterase/pectinesterase inhibitor 12 \\
\hline
\end{tabular}

RS, Response to stress (GO: 0006950, FDR: 0.001); CA, Catalytic activity (GO: GO:0003824, FDR: 0.0023).

similarity with the defense response, we also looked at highly up-regulated genes in the sepal rather than in the senescent leaf and found significant enrichments in the categories "Response to external stimulus" and "Response to endogenous stimulus" (Table 5 and Table S1). These responses are defined as any process that results in a change in the state or activity of a cell or organism, e.g., in terms of secretion or enzyme production as a result of an external stimulus. The result therefore is further support for a sepal specific metabolic response different to the one observed in leaf senescence. Finally, a similar comparison between the petal and the senescent leaf transcriptomes sees the categories "Cell wall" and "External encapsulating structures" enriched in the petal (Table 6 and Table S1).

\section{THE FLOWER SHOWS ELEVATED LEVELS OF SALICYLIC ACID}

Given that the transcriptome analysis showed that the SA-induced $P R-1$ was over expressed in sepals in stage 15 (Table 2), we were interested to discover if SA accumulates in sepals and petals. We assessed the total (free and sugar-conjugated) and free SA levels in leaves, sepals and petals of Arabidopsis Col-0. The glucosylated form makes the largest part of the total SA content. In the leaves it is 64\%, in the sepal 62 and $79 \%$ in the petal (Figure 2). It is noteworthy that free and total SA content were significantly higher in sepals as compared to leaves $(\approx 10$-fold $)$. In petals the free SA levels were similar to those in the sepals while the total SA 
Table 4 | Genes highly up-regulated at stage 15 sepal vs. rosette leaves.

\begin{tabular}{|c|c|c|}
\hline Gene ID & GO cat. & Annotation \\
\hline AT2G38540 & & Non-spec. lipid transfer prot., binds CAM \\
\hline AT1G35310 & & MLP-like protein, defense response \\
\hline AT5G45890 & CA & Senescence-assoc. gene 12 (Cys-type pep.) \\
\hline AT2G37770 & CA & NADPH-dependent aldo-keto reductase \\
\hline АТЗG13400 & & Multicopper oxidase \\
\hline AT1G68620 & $\mathrm{CA}$ & Hydrolase superfamily protein \\
\hline AT2G02990 & CA & Ribonuclease 1 \\
\hline AT4G24000 & CA & Cellulose synthase G2 \\
\hline AT4G23680 & & Polyketide cyclase, lipid transport \\
\hline AT1G02790 & CA & Exopolygalacturonase \\
\hline AT4G15620 & & UPF 497 membrane protein \\
\hline AT3G27810 & & MYB21, R2R3-MYB family \\
\hline AT1G80160 & CA & Lactoylglutathione lyase \\
\hline AT5G15800 & & Developmental protein SEPALLATA 1 \\
\hline AT1G54570 & CA & Acyltransferase-like protein, chloroplast \\
\hline AT2G47030 & CA & Pectinesterase 4 \\
\hline AT4G33040 & CA & Glutaredoxin-C6 \\
\hline AT5G02580 & & Unknown protein \\
\hline AT1G61563 & & Rapid Alkalinisation Factor 8 \\
\hline AT2G41380 & CA & S-adenosyl-L-met.-dep. methyl transferase \\
\hline AT1G09500 & CA & Alcohol dehydrogenase \\
\hline AT1G65480 & & Flowering locus $\mathrm{T}$, promotes flowering \\
\hline AT1G61680 & CA & Linalool synthase, chloroplastic \\
\hline AT4G39480 & & Cytochrome p450, family 96 protein \\
\hline AT5G07430 & CA & Pectin lyase-like superfamily protein \\
\hline
\end{tabular}

CA, Catalytic activity (GO: 0003824, FDR: 0.004).

was considerably higher (Figure 2A). We also performed experiments to detect the levels of total and free SA in leaves and in floral organs of plants carrying the nah $G$ transgene salicylate hydroxylase that converts SA to catechol. As expected, nah $G$ plants accumulated just detectable quantities of total and free SA without any significant differences among the three organs examined (Figure 2).

\section{PLANT RESPONSES TO INFECTION WITH GOLOVINOMYCES CICHORACEARUM}

The markedly higher SA content in Col-0 sepals and petals compared to leaves might suggest a different defense reaction of these organs against biotrophic pathogens. To test this, Col-0 and SAdeficient nahG plants were inoculated with G. cichoracearum. At 4 days post-inoculation (dpi) all leaves of both genotypes were infected, as seen from the count of the Trypan blue stained colonies (Figure 3A and Table 7). However, on SA-deficient nah $G$ leaves, the pathogen produced significantly more conidiophores and conidia per colony than on the Col-0 leaves (Table 7). In contrast, at the same time (4 dpi) only on a very few sepals did G. cichoracearum form colonies and they did not develop conidiophores and conidia. In general, the colony growth on sepals appeared to be impaired in comparison to the leaf (Figure 3A). At $4 \mathrm{dpi}$, no colonies were detected on inoculated petals in both Col-0 and nah $G$ genotypes (Figure 3). We also carried out the
Table 5 | Genes highly up-regulated at stage 15 sepals vs. senescent leaves.

\begin{tabular}{|c|c|c|}
\hline Gene ID & GO cat. & Annotation \\
\hline AT1G35310 & & MLP-like protein, defense response \\
\hline AT2G38540 & & Non-spec. lipid transfer prot., binds CAM \\
\hline AT1G19580 & & Carbonic anhydrase, chloroplastic \\
\hline AT5G59310 & REN & Lipid-transfer prot. 4, abiotic stress \\
\hline AT1G55260 & & Lipid-transfer protein \\
\hline AT5G24150 & & Squalene monooxygenase 1,1 \\
\hline AT5G15800 & & Developmental protein SEPALLATA 1 \\
\hline АT3G27810 & REN & MYB21, R2R3-MYB family \\
\hline AT1G65480 & & Flowering locus T, promotes flowering \\
\hline AT4G15210 & & Cytosolic $\beta$-amylase \\
\hline AT1G02205 & & Production of stem epicuticular wax \\
\hline AT1G61680 & & Linalool synthase, chloroplastic \\
\hline AT4G14690 & & Early light-induced protein. ELIP \\
\hline AT1G69120 & & Apetala 1 \\
\hline AT1G29670 & & GDSL-like lipase \\
\hline AT1G24260 & & MADs box transcription factor \\
\hline AT4G39480 & & Cytochrome p450, family 96 protein \\
\hline AT2G02990 & REX REN & Ribonuclease 1 \\
\hline AT1G66120 & & Butyrate metabolic process \\
\hline AT4G23600 & REX REN & Coronatine-ind., JA and ABA resp. \\
\hline AT2G37770 & & NADPH-dependent aldo-keto reductase \\
\hline AT3G11480 & REX & Methyltransferase for SA and benzoic acid \\
\hline AT2G06850 & REX REN & Xylogluc. endotransglucosylase/hydrol. \\
\hline AT5G57560 & REX REN & Xylogluc. endotransglucosylase/hydrol. \\
\hline AT1G35140 & & EXL1 is involved in the C-starvation \\
\hline
\end{tabular}

REX, Response to external stimulus (GO: 0009605, FDR: 0.00045); REN, Response to endogenous stimulus (GO: 0009719, FDR: 0.0017).

G. cichoracearum inoculation on detached Col-0 rosette leaves, sepals and petals incubated in Petri dishes on water-agar medium. At 2 dpi, only a small number of colonies were found on leaves, while the number of colonies was significantly higher at $4 \mathrm{dpi}$. At $4 \mathrm{dpi}$, only a single colony was detected on all sepals examined (Figure 3B) and no germinated conidia were found on petal surfaces (Figure 3B). Similar results were obtained in the floral organs detached from nah $G$ plants. Moreover, at 4 dpi in the leaves of the mutant fungal colonies were more developed with respect to those detected on Col-0 (Figure S1). The results of G. cichoracearum infection quantification are reported in Table 7 and Figure 4. To further assess the level of G. cichoracearum infection on Col-0 and nahG leaves and sepals, the fungal biomass was quantified by PCR analysis at 2 and 4 dpi. At 2 dpi fungal biomass was similar in the leaves of both genotypes whereas at 4 dpi, G. cichoracearum biomass was significantly higher in nah $G$ leaves (Figure 4). On Col-0 and $n a h G$ sepals, the fungal biomass was similar and significantly lower than that of the leaves; moreover, it did not increase at 4 dpi (Figure 4). The genomic DNA quantification of G. cichoracearum was restricted to the leaves and sepals since the petals were never infected by G. cichoracearum.

Usually, on infected host surfaces, G. cichoracearum shows abundant conidiation that is visible to the naked eye, starting 7 dpi, even though there is wide variability in infection phenotypes 
Table 6 | Genes highly up-regulated at stage 15 petals vs. senescent leaves.

\begin{tabular}{|c|c|c|}
\hline Gene ID & GO cat. & Annotation \\
\hline AT5G25460 & CW EXE & DUF 642, plant-type cell wall function \\
\hline AT1G61680 & & Linalool synthase, chloroplastic \\
\hline AT3G27810 & & MYB 21, R2R3-MYB family \\
\hline AT1G55260 & & Lipid-transfer protein \\
\hline AT2G06850 & CW EXE & Xylogluc. endotransglucosylase/hydrolase \\
\hline AT1G29670 & CW EXE & GDSL-like lipase \\
\hline AT2G10940 & & Lipid-transfer protein \\
\hline AT2G38540 & CW EXE & Non-spec. lipid transfer prot., binds CAM \\
\hline AT1G35310 & & MLP-like protein, defense response \\
\hline AT4G39480 & & Cytochrome $\mathrm{p} 450$, family 96 protein \\
\hline AT3G53300 & & Putative cytochrome p 450 \\
\hline AT1G02205 & & Production of stem epicuticular wax \\
\hline AT1G66120 & & Butyrate metabolic process \\
\hline AT3G54340 & & Apetala3 \\
\hline AT3G01980 & & NAD(P)-bind. Rossmann-fold protein \\
\hline AT1G55330 & & Arabinogalactan peptide 21 \\
\hline AT2G17880 & & Chaperone DnaJ-domain superfam. prot. \\
\hline AT5G45950 & & GDSL-like Lipase \\
\hline AT4G32460 & CW EXE & Unknown protein in the cell wall \\
\hline AT5G62360 & $\mathrm{CW}^{*}$ & Unknown protein in the cell wall \\
\hline AT4G25830 & & UPF0497 membrane protein \\
\hline AT5G47550 & CW EXE & Cysteine proteinase inhibitor 5 \\
\hline AT1G12090 & & Extensin-like protein (ELP) \\
\hline AT1G24260 & & Sepallata 3 \\
\hline AT1G11850 & & Unknown protein \\
\hline
\end{tabular}

CW, Cell wall (GO: 000 5618, FDR: 4.5e-06); EXE, External encapsulating structure (GO: 0030312, FDR: 4.5e $e^{-06}$ ); *Not included in the AgriGO analysis.

in terms of isolate virulence, environmental conditions (such as temperature, humidity and light intensity) and host susceptibility. Here, visual assessment of inoculated plants at $7 \mathrm{dpi}$ revealed chlorotic and necrotic lesions on $n a h G$ leaves and the leaf surfaces had the white powdery appearance caused by mycelia, conidiphores and conidia. At the same time, only small chlorotic lesions and limited conidiation were detectable on Col-0 leaves. In contrast, no disease symptoms or pathogen structures were detectable on flowers of both of these genotypes (Figure 5). On the other hand, our microscopic investigation (Figure 3) clearly showed that at 4 dpi the spray-inoculated conidia had not germinated or only just germinated on the surface of the floral organs, without development of fungal hyphae. The fungal DNA quantification confirmed an absence of growth of the fungus on Col-0 and $n a h G$ sepals (Figure 4), which indicated that these reproductive structures are resistant to G. cichoracearum infection.

\section{PLANT RESPONSES TO INFECTION WITH BOTRYTIS CINEREA}

To further investigate possible different responses of the floral organs and, in particular, of the sepals against necrotrophic pathogens, the Col- 0 and SA-deficient nah $G$ plants were sprayinoculated with Botrytis cinerea and the lesion development was measured. Visual assessment of spray-inoculated Arabidopsis plants at 2 dpi showed no symptoms on Col- 0 and nah $G$ leaves.
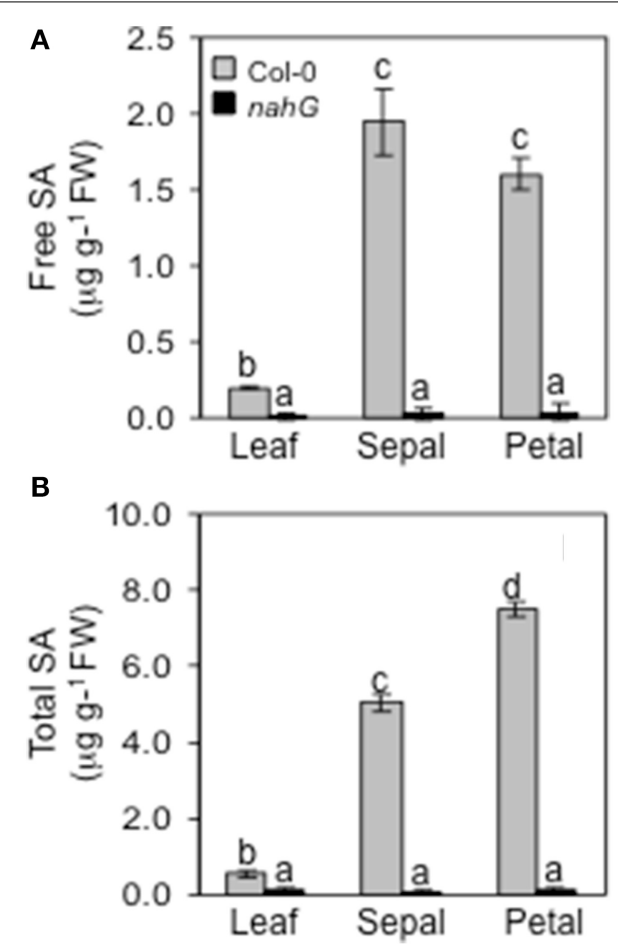

FIGURE 2 | Endogenous levels of free and total SA. Free (A) and total (B) endogenous SA content in leaves, sepals and petals of Col-0 and nah plants were determined. Leaves were sampled from 4 week old plants, whereas sepals and petals were taken from 6 to 7 week old plants at stage 14-15 of flower development. Bars represent the mean \pm SE and different letters indicate statistically significant differences using Duncan's multiple range test $(P \leq 0.01)$.

In contrast, sepals and petals of both genotypes were necrotic. Moreover, gray mycelia started to appear on the floral surface (Figure 6A). At $7 \mathrm{dpi}$, the gray fungal structures completely covered the inflorescence of both genotypes. At the same time, clear symptoms (chlorosis and rot) were detectable on both Col-0 and nah $G$ leaves (Figure 6A) and no difference in susceptibility was noted between Col- 0 and $n a h G$ plants (Figure 6A). The lack of a significant difference in susceptibility of Col- 0 and $n a h G$ leaves to $B$. cinerea was confirmed by lesion area measurements on drop-inoculated detached leaves at 3 dpi (Figure 6B). Thus, in this system, in contrast to the responses against the biotroph, the susceptibility to the necrotroph $B$. cinerea showed no differences between flowers and leaves, and between the two genotypes, which suggests a limited role for SA in the $B$. cinerea defense response.

\section{DISCUSSION}

The first indication of the presence of PR proteins in the flower comes from work on tobacco and, perhaps most importantly, it was demonstrated that there is a pathogen-independent induction (Lotan et al., 1989) and that PR proteins in the sepal are induced as part of the developmental program. More recently it was shown that tobacco and petunia contain chemically distinct floral defensins, basic small proteins that can retard the growth 


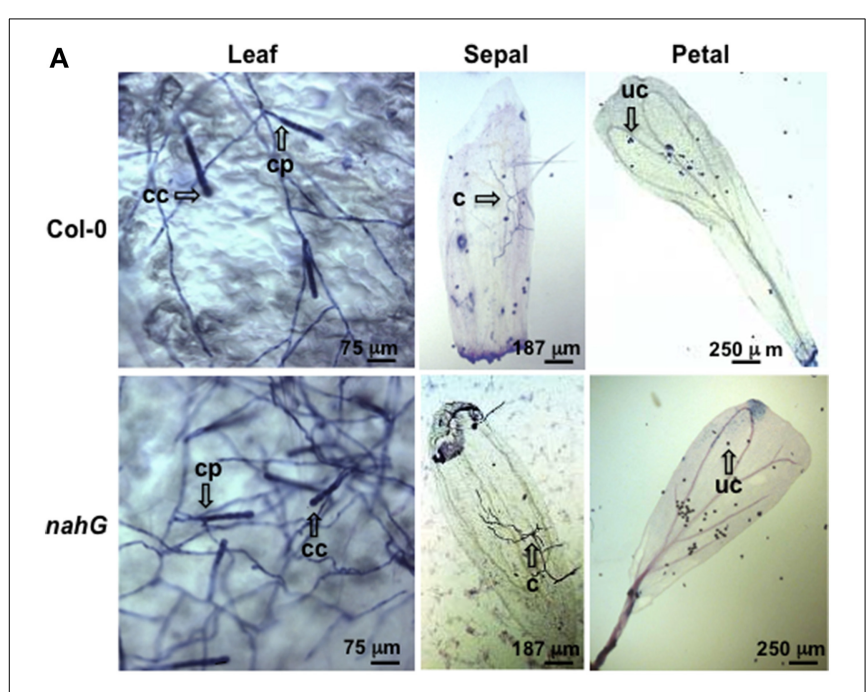

B

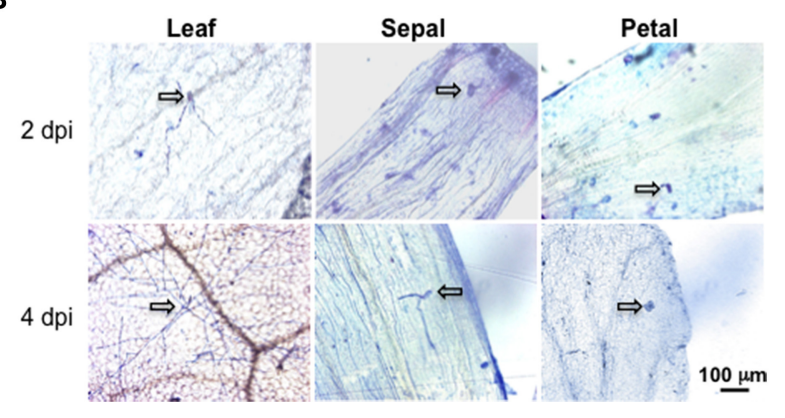

FIGURE 3 | Trypan blue staining for the detection of Golovinomyces cichoracearum. (A) Representative microscopic images of leaves, sepals and petals from Col-0 and nahG plants stained with Trypan blue at 4 days post-spray inoculation with a conidial suspension of $G$. cichoracearum. Leaves were sampled from 4 week old plants, whereas sepals and petals were taken from 6 to 7 week old plants at stages 14-15. Observations were carried out on a minimum of 50 samples. Arrows indicate a conidiophore (cp) and chain of conidia (cc) in leaves, colony without conidiphore (c) in sepals and ungerminated conidia (uc) in petals. (B)

Representative microscopic images of detached leaves, sepals and petals from Col-0 stained with Trypan blue at 2 and 4 days post-spray inoculation with a conidial suspension of $G$. cichoracearum. Arrows indicates developed colonies in leaves and ungerminated or just germinated conidia in sepals and petals.

of fungi, oomycetes, and gram-positive bacteria. These defense mechanisms are specifically induced during the early stages of flower development (Lay et al., 2003) and operate in the outermost cell layers of sepals, petals, anthers, and styles, where they presumably serve in the first line of defense against pathogens.

Given these observations we hypothesized that the sepal may serve not just as a physical but also as a chemical defense barrier that protects the developing reproductive organs. The sepal has a very distinct morphology that includes polyploid giant cells (Figure 1). The biological role of these giant cells of the sepal is still not clear, but we know that they are the result of endoreduplication (Roeder et al., 2010). Endoploidy is essential for normal development and physiology in many different organisms. There are cells that go into endoreplication as part of terminal differentiation to enable specialized function (Lee et al., 2009). Plants grow by increasing cell numbers, cell size or both. Since increased DNA content correlates with increased cell size, endoreplication is a highly efficient growth mode since it reduces the cell (and cell wall) surface to volume ratio. Thus, such a growth mode may be particularly desirable when rapid growth must occur or high metabolic activity is required (Inzé and De Veylder, 2006). It is generally assumed that endoreplicationassociated growth is indicative for cell types that perform specific biological functions. It has recently been reported that in Arabidopsis increasing gene copy number by localized endoreduplication, mediated by MYB3R4 (AT5G11510), may serve as a mechanism to meet the enhanced metabolic demands imposed by, e.g., the pathogenic biotroph fungus Golovinomyces orontii that depends entirely on the nutrient supply from the host (Chandran et al., 2010). Furthermore, there are numerous examples in other systems where specific cell types undergo endoreduplication and interestingly, it appears that these cell types often have roles in secretion and in some cases secretion of antimicrobial compounds (Reilly et al., 1994; Dai et al., 2010). For these reasons and based on the transcriptional profiles (Tables 1-6), we hypothesize that the sepal is in an heightened state of biochemical defense with many genes induced that encode enzymes that catalyze the production of defense components targeted for secretion into the extracellular space. In addition, we propose that the giant cells of the sepal are actually the metabolic factories that are synthesizing the defensive proteins as a preventive and/or protective measure. SA is a well-characterized molecule that regulates the activation and potentiation of plant defense responses (Vlot et al., 2009). However, the activation of defense responses is not the only regulatory role of SA. The first reported physiological responses to SA were the induction of thermogenesis through the activation of the mitochondrial alternative oxidase in Arum flowers (Raskin et al., 1987, 1989). Since then several other functions have been assigned to SA, including a regulatory role in flowering (Martinez et al., 2004), regulation of gene expression during leaf senescence (Morris et al., 2000) and regulation of cell growth by specifically affecting cell enlargement, endoreduplication and/or cell division. In addition, methyl SA is a volatile compound, and like other methyl esters (e.g., methyl benzoate, methyl cinnamate, methyl jasmonate) it is a widespread fragrant component in the plant kingdom contributing significantly to the floral scent output (Knudsen and Tollsten, 1993). Our data show very high constitutive levels of free and conjugated SA in both sepals and petals, whereas in pathogen-unchallenged leaves the SA content was very low. The high SA levels correlate well with the up-regulation of PRs protein encoding genes revealed by the transcriptome analysis.

We challenged leaves and inflorescence of Col-0 and nahG plants with the biotrophic fungus $G$. cichoracearum and the necrotrophic $B$. cinerea with the aim to clarify whether the defense program against these pathogens is enhanced in the inflorescence with respect to the leaves. When the leaves were infected with the fungus $G$. cichoracearum, the SA-deficient transgenic $n a h G$ plants were more sensitive than Col-0 and this is consistent with the SA-dependent resistance against the biotrophic pathogen in Arabidopsis leaves (Ellis et al., 2002). However, sepals 
Table 7 | Quantitation of Golovinomyces cichoracearum growth on Col-0 and nahG leaves and sepals.

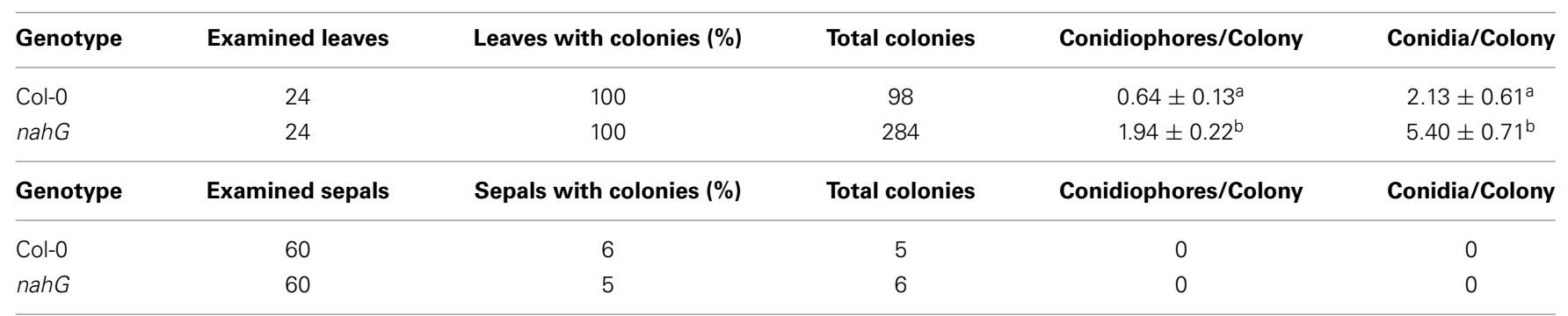

Leaves and sepals of Col-0 and nahG plants were sprayed with a conidial suspension of G. cichoracearum. Leaves were sampled from 4 week old plants, whereas

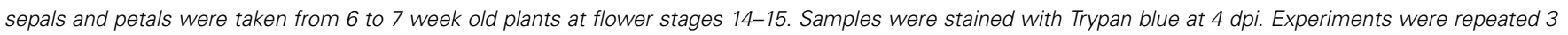
times with similar results. Conidiophores and conidia were counted on randomly selected single fungal colonies on a total of 24 leaves and 60 sepals per genotype. Data represent the mean $\pm S E$. Different letters indicate statistically significant differences using Duncan's multiple range test (P $\leq 0.01)$.

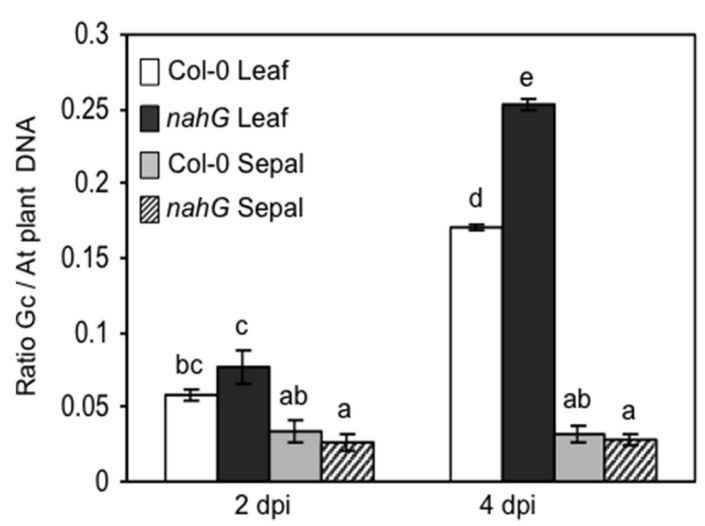

FIGURE 4 | Genomic DNA quantification of Golovinomyces cichoracearum biomass. G. cichoracearum biomass was quantified by semi-quantitative PCR in leaves and sepals of Col-0 and nah $G$ plants at 2 and $4 \mathrm{dpi}$ and expressed as the ratio between fungal and plant DNA. Leaves were sampled from 4 week plants, whereas sepals and petals were taken from 6 to 7 week old plants, at stage 14-15. Amplification was performed using specific primers derived from the ribosomal ITS region of the fungus and primers designed for the Arabidopsis elongation factor (AT5G19510). Bars represent the mean \pm SE of two biological replicates (a pool of leaves or sepals from 10 plants per replicate) analyzed in triplicate by PCR assay. Two-way (genotype and time) analysis of variance was performed. Different letters indicate statistically significant differences using Duncan's multiple range test $(P \leq 0.01)$.

and petals of Col- 0 and nah $G$ are both resistant to the biotroph with no or very few colonies forming on petals and sepals, respectively. Moreover, G. cichoracearum did not develop conidiphores and conidia on sepals. Since sepals and petals of Col-0 and SA-deficient plants were resistant to G. cichoracearum, we argue that in these organs the resistance to biotrophic pathogen is not exclusively or critically dependent on SA but depends on constitutive up-regulation of stress-responsive genes in flower. This interpretation is supported by the transcriptional analysis that shows a high induction of genes encoding proteins with a role in responses to chemical stimuli in the sepal (stage 12) and genes encoding proteins with a role in responses to biotic and chemical stimuli (stage 15). A comparison between the highly up-regulated genes in the sepal as compared to those in the

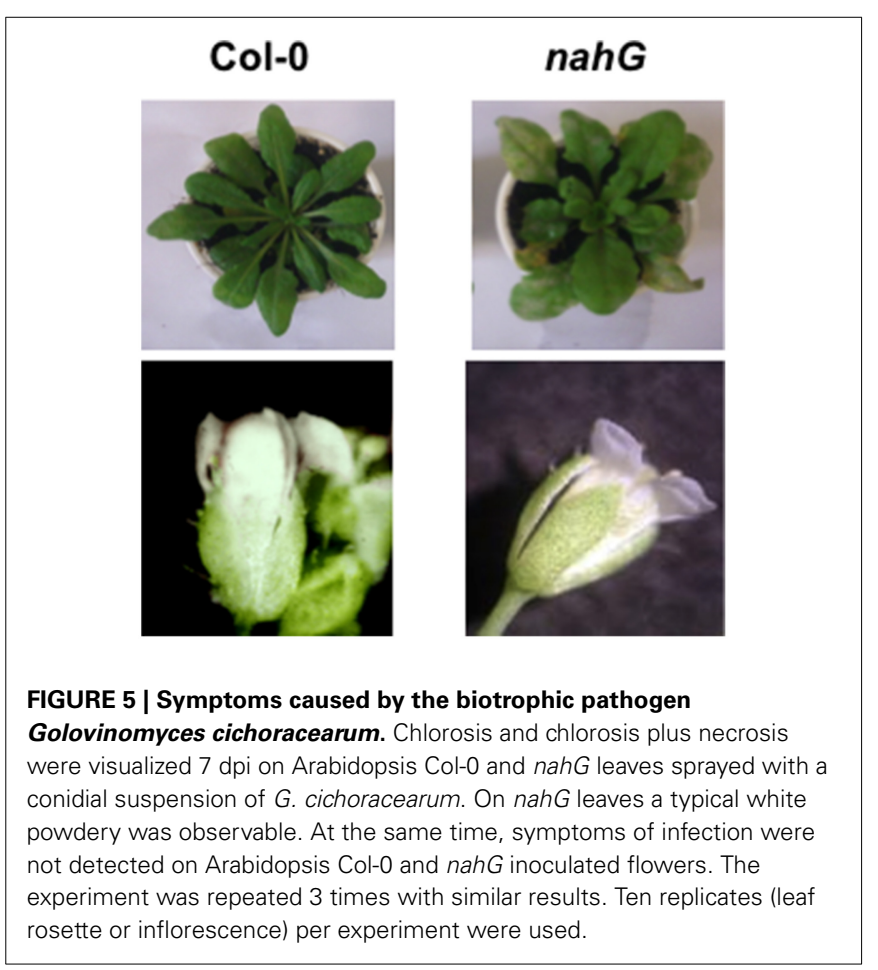

petal reveals an enrichment in the categories "Catalytic activity" and "Response to stress" again point to an organ-specific and enhanced defense program (Table 3). NahG plants do not accumulate SA or camalexin (Nawrath and Metraux, 1999). However, there are many reports that show PRs activation after pathogen infection (Nawrath and Metraux, 1999; Govrin and Levine, 2002) thus suggesting that also in $n a h G$ mutant flowers there is a constitutive activation of defense mechanisms able to protect the flower against biotrophic pathogen infection. This point remains to be further elucidated and will be resolved when the transcriptome of nah $G$ sepals becomes available.

Given the short lifespan of sepals and petals, and the possibility of senescence-related defense responses, we compared the sepal and petal transcriptomes to the transcriptome of senescent leaves (Tables 5, 6). In the case of the sepal, we noted enrichment in genes encoding proteins with catalytic activity (Tables 5 


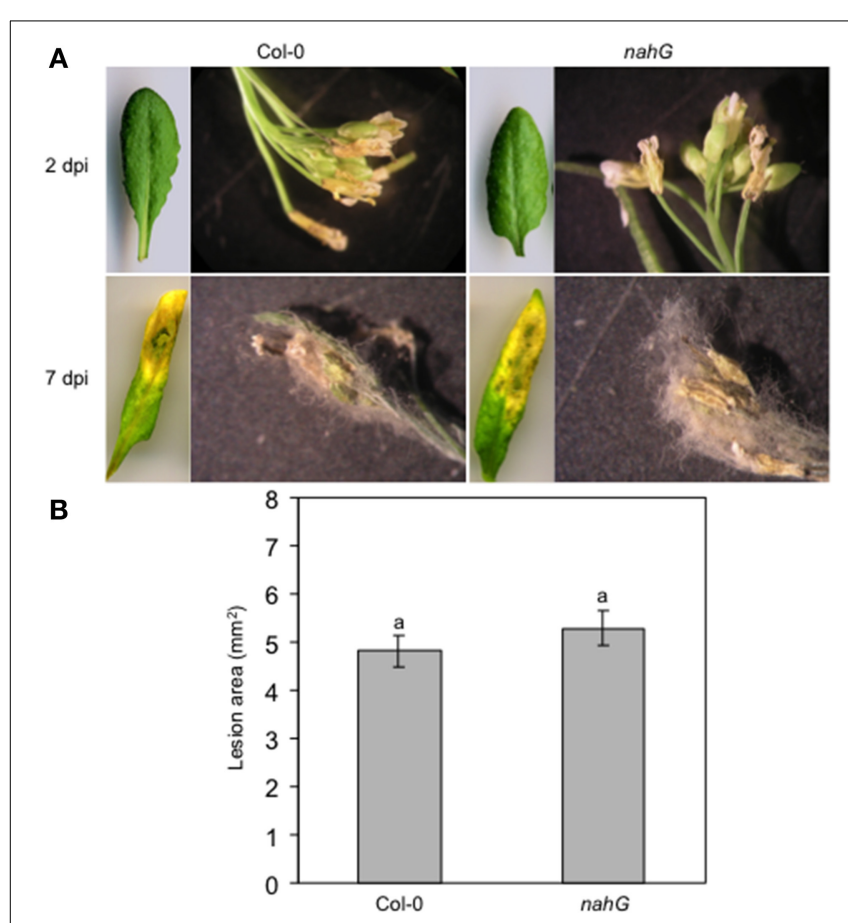

FIGURE 6 | Col-0 and nahG response to the necrotrophic pathogen Botrytis cinerea. (A) Progression over time of symptoms and signs on B. cinerea spray inoculated Col-0 and nahG leaves and flowers (see the legend of Figure $\mathbf{3}$ for sampling of plant material). On both genotypes, no leaf symptoms were detectable at 2 dpi while at $7 \mathrm{dpi}$ chlorosis, necrosis and rot affected almost the entire leaf surface. At 2 dpi clear symptoms are seen in Col-0 and nah $\mathrm{G}$ flowers. At 7 dpi the pathogen completely covers the flower. The experiment was repeated 3 times with similar results. Ten replicates were used in each experiment. (B) Lesion area measured at $3 \mathrm{dpi}$ in Col-0 and nah $\mathrm{G}$ leaves inoculated by placing a two $5 \mu \mathrm{L}$ drop of conidial suspension on the upper surface of detached leaves. The experiment was repeated 3 times and resulted in 84 lesions observed on 42 leaves in each genotype. Bars represent the mean \pm SE and different letters indicate statistically significant differences using Duncan's multiple range test $(P \leq 0.01)$.

and Table S1) and in the case of the petal, an overrepresentation of genes encoding proteins with a role in cell wall function and external encapsulating structures (Tables 6 and Table S1). These results point to specific functions beyond the leaf senescence program and are conceivably indicators of enhanced functional and structural defense components. Additionally, the Arabidopsis petal with its absence of photosynthesis (Pyke and Page, 1998) is hardly particularly attractive to biotrophic pathogens.

In contrast to the response to the biotroph pathogen, the response to the necrotroph $B$. cinerea showed no difference between the flower and the leaves. In addition, the $B$. cinerea phenotype of nah $G$ was indistinguishable from Col-0 suggesting a limited role for SA in the interaction between $B$. cinerea and Col-0 in Arabidopsis. Contrary to previous reports (Govrin and Levine, 2002; Ferrari et al., 2003), in our experiments nahG plants had resistance to $B$. cinerea that was comparable to Col0 plants as previously reported (Thomma et al., 1998; Veronese et al., 2004; Abuqamar et al., 2006). These discrepancies may be caused by differences in the Botrytis strain or the methods of inoculation. In conclusion, the same $B$. cinerea disease susceptibility of leaves and flowers and Col-0 and nahG plants suggests that neither constitutive stress-responsive gene induction in sepals nor SA accumulation can prevent infections by this necrotrophic pathogen. On the other hand, induced defense responses to pathogens are mediated by multiple signal transduction pathways. While SA-mediated defenses are prominent against biotrophic pathogens, jasmonate/ethylene signaling exerts a major influence on plant response to necrotrophic pathogens such as Botrytis cinerea (Thomma et al., 1998, 1999). In addition, elicitors released from the cell wall during pathogen infection and genes involved in the biosynthesis of secondary metabolites play an important role in determining the enhanced resistance against $B$. cinerea through a signaling pathway activated by pathogenassociated molecular pattern molecules and, therefore, independently of SA, JA, and ET (Ferrari et al., 2007). Furthermore, it has been demonstrated that $B$. cinerea can induce multiple defense responses in Arabidopsis resembling to hypersensitive response (HR) (Govrin and Levine, 2002), but contrary to the effect on biotrophic pathogens, HR facilitates rapid growth and spread of this necrotrophyic pathogen.

In summary, we report that the sepal and petal express a distinct set of genes that encode proteins with a role in defense against pathogens. This tissue specific transcriptional program is reflected in the enhanced host responses, in particular to biotrophic pathogens. We also propose that the giant cells in the sepal are the metabolic factories that provide the chemical defense shield and we are currently planning to experimentally test this hypothesis.

\section{AUTHOR CONTRIBUTIONS}

CG, SP, LE, MQ, and LX conceived and designed the experiments. LE and MQ performed the experiments. AD and CG performed the bioinformatics analyses. LE, SP, AD, and CG analyzed the data. CG and SP wrote the paper.

\section{ACKNOWLEDGMENT}

The authors thank Lee Staff for helpful suggestions and critical reading of the manuscript.

\section{SUPPLEMENTARY MATERIAL}

The Supplementary Material for this article can be found online at: http://www.frontiersin.org/journal/10.3389/fpls.2015.00079/ abstract

Table S1 | Sepal gene expression at different stages.

\section{REFERENCES}

Abuqamar, S., Chen, X., Dhawan, R., Bluhm, B., Salmeron, J., Lam, S., et al. (2006). Expression profiling and mutant analysis reveals complex regulatory networks involved in Arabidopsis response to Botrytis infection. Plant J. 48, 28-44. doi: 10.1111/j.1365-313X.2006.02849.x

Andriotis, V. M., and Rathjen, J. P. (2006). The Pto kinase of tomato, which regulates plant immunity, is repressed by its myristoylated $\mathrm{N}$ terminus. J. Biol. Chem. 281, 26578-26586. doi: 10.1074/jbc.M603197200

Barrett, T., Troup, D. B., Wilhite, S. E., Ledoux, P., Evangelista, C., Kim, I. F., et al. (2011). NCBI GEO: archive for functional genomics data sets-10 years on. Nucl. Acids Res. 39, D1005-D1010. doi: 10.1093/nar/ gkq1184 
Bossinger, G., and Smyth, D. R. (1996). Initiation patterns of flower and floral organ development in Arabidopsis thaliana. Development 122, 1093-1102.

Chandran, D., Inada, N., Hather, G., Kleindt, C. K., and Wildermuth, M. C. (2010). Laser microdissection of Arabidopsis cells at the powdery mildew infection site reveals site-specific processes and regulators. Proc. Natl. Acad. Sci. U.S.A. 107, 460-465. doi: 10.1073/pnas.0912492107

Chen, R. S., Chu, C., Cheng, C. W., Chen, W. Y., and Tsay, J. G. (2008). Differentiation of two powdery mildews of sunflower (Helianthus annuus) by a PCR-mediated method based on ITS sequences. Eur. J. Plant Pathol. 121, 1-8. doi: 10.1007/s10658-007-9234-5

Cheng, H., Song, S., Xiao, L., Soo, H. M., Cheng, Z., Xie, D., et al. (2009). Gibberellin acts through jasmonate to control the expression of MYB21, MYB24, and MYB57 to promote stamen filament growth in Arabidopsis. PLoS Gen. 5:e1000440. doi: 10.1371/journal.pgen.1000440

Dai, X., Wang, G., Yang, D. S., Tang, Y., Broun, P., Marks, M. D., et al. (2010). TrichOME: a comparative omics database for plant trichomes. Plant Physiol. 152, 44-54. doi: 10.1104/pp.109.145813

de Jonge, R., Van Esse, H. P., Maruthachalam, K., Bolton, M. D., Santhanam, P., Saber, M. K., et al. (2012). Tomato immune receptor Vel recognizes effector of multiple fungal pathogens uncovered by genome and RNA sequencing. Proc. Natl. Acad. Sci. U.S.A. 109, 5110-5115. doi: 10.1073/pnas.1119623109

Du, Z., Zhou, X., Ling, Y., Zhang, Z., and Su, Z. (2010). agriGO: a GO analysis toolkit for the agricultural community. Nucl. Acids Res. 38, W64-W70. doi: 10.1093/nar/gkq310

Edgar, R., Domrachev, M., and Lash, A. E. (2002). Gene Expression Omnibus: NCBI gene expression and hybridization array data repository. Nucl. Acids Res. 30, 207-210. doi: 10.1093/nar/30.1.207

Ellis, C., Karafyllidis, I., and Turner, J. G. (2002). Constitutive activation of jasmonate signaling in an Arabidopsis mutant correlates with enhanced resistance to Erysiphe cichoracearum, Pseudomonas syringae, and Myzus persicae. Mol. Plant Microbe. Interact. 15, 1025-1030. doi: 10.1094/MPMI.2002.15.10.1025

Eulgem, T., and Somssich, I. E. (2007). Networks of WRKY transcription factors in defense signaling. Curr. Opin. Plant Biol. 10, 366-371. doi: 10.1016/j.pbi.2007.04.020

Ferrari, S., Galletti, R., Denoux, C., De Lorenzo, G., Ausubel, F. M., and Dewdney, J. (2007). Resistance to Botrytis cinerea induced in Arabidopsis by elicitors is independent of salicylic acid, ethylene, or jasmonate signaling but requires PHYTOALEXIN DEFICIENT3. Plant Physiol. 144, 367-379. doi: 10.1104/pp.107.095596

Ferrari, S., Plotnikova, J. M., De Lorenzo, G., and Ausubel, F. M. (2003). Arabidopsis local resistance to Botrytis cinerea involves salicylic acid and camalexin and requires EDS4 and PAD2, but not SID2, EDS5 or PAD4. Plant J. 35, 193-205. doi: 10.1046/j.1365-313X.2003.01794.x

Garavaglia, B. S., Thomas, L., Gottig, N., Zimaro, T., Garofalo, C. G., Gehring, C., et al. (2010). Shedding light on the role of photosynthesis in pathogen colonization and host defense. Commun. Integr. Biol. 3, 382-384. doi: 10.4161/cib.3.4.12029

Gottig, N., Garavaglia, B. S., Daurelio, L. D., Valentine, A., Gehring, C., Orellano, E. G., et al. (2008). Xanthomonas axonopodis pv. citri uses a plant natriuretic peptide-like protein to modify host homeostasis. Proc. Natl. Acad. Sci. U.S.A. 105, 18631-18636. doi: 10.1073/pnas.0810107105

Govrin, E. M., and Levine, A. (2002). Infection of Arabidopsis with a necrotrophic pathogen, Botrytis cinerea, elicits various defense responses but does not induce systemic acquired resistance (SAR). Plant Mol. Biol. 48, 267-276. doi: 10.1023/A:1013323222095

Inzé, D., and De Veylder, L. (2006). Cell cycle regulation in plant development. Annu. Rev. Genet. 40, 77-105. doi: 10.1146/annurev.genet.40.110405.090431

Jin, J. B., Jin, Y. H., Lee, J., Miura, K., Yoo, C. Y., Kim, W. Y., et al. (2008). The SUMO E3 ligase, AtSIZ1, regulates flowering by controlling a salicylic acid-mediated floral promotion pathway and through affects on FLC chromatin structure. Plant J. 53, 530-540. doi: 10.1111/j.1365-313X.2007.03359.x

Johnson, C., Boden, E., and Arias, J. (2003). Salicylic acid and NPR1 induce the recruitment of trans-activating TGA factors to a defense gene promoter in Arabidopsis. Plant Cell 15, 1846-1858. doi: 10.1105/tpc.012211

Kenton, P., Darby, R. M., Shelley, G., and Draper, J. (2000). A PR-5 gene promoter from Asparagus officinalis (AoPRT-L) is not induced by abiotic stress, but is activated around sites of pathogen challenge and by salicylate in transgenic tobacco. Mol. Plant Pathol. 1, 367-378. doi: 10.1046/j.1364-3703.2000. 00040.x
Kliebenstein, D. J. (2012). Plant defense compounds: systems approaches to metabolic analysis. Annu. Rev. Phytopathol. 50, 155-173. doi: 10.1146/annurevphyto-081211-172950

Knudsen, J. T., and Tollsten, L. (1993). Trends in floral scent chemistry in pollination syndromes: floral scent composition in moth-pollinated taxa. Bot. J. Linn. Soc. 113, 263-284. doi: 10.1111/j.1095-8339.1993.tb00340.x

Kolar, J., and Senkova, J. (2008). Reduction of mineral nutrient availability accelerates flowering of Arabidopsis thaliana. J. Plant Physiol. 165, 1601-1609. doi: 10.1016/j.jplph.2007.11.010

Kutter, C., Schob, H., Stadler, M., Meins, F. Jr., and Si-Ammour, A. (2007). MicroRNA-mediated regulation of stomatal development in Arabidopsis. Plant Cell 19, 2417-2429. doi: 10.1105/tpc.107.050377

Lawton, K., Weymann, K., Friedrich, L., Vernooij, B., Uknes, S., and Ryals, J. (1995). Systemic acquired resistance in Arabidopsis requires salicylic acid but not ethylene. Mol. Plant Microbe. Interact. 8, 863-870. doi: 10.1094/MPMI-8-0863

Lay, F. T., Brugliera, F., and Anderson, M. A. (2003). Isolation and properties of floral defensins from ornamental tobacco and petunia. Plant Physiol. 131, 1283-1293. doi: 10.1104/pp.102.016626

Lebel, E., Heifetz, P., Thorne, L., Uknes, S., Ryals, J., and Ward, E. (1998). Functional analysis of regulatory sequences controlling PR-1 gene expression in Arabidopsis. Plant J. 16, 223-233. doi: 10.1046/j.1365-313x.1998.00288.x

Lee, H. O., Davidson, J. M., and Duronio, R. J. (2009). Endoreplication: polyploidy with purpose. Genes Dev. 23, 2461-2477. doi: 10.1101/gad.1829209

Lotan, T., Ori, N., and Fluhr, R. (1989). Pathogenesis-related proteins are developmentally regulated in tobacco flowers. Plant Cell 1, 881-887. doi: 10.1105/tpc.1.9.881

March-Diaz, R., Garcia-Dominguez, M., Lozano-Juste, J., Leon, J., Florencio, F. J., and Reyes, J. C. (2008). Histone H2A.Z and homologues of components of the SWR1 complex are required to control immunity in Arabidopsis. Plant J. 53, 475-487. doi: 10.1111/j.1365-313X.2007.03361.x

Martinez, C., Pons, E., Prats, G., and Leon, J. (2004). Salicylic acid regulates flowering time and links defence responses and reproductive development. Plant J. 37, 209-217. doi: 10.1046/j.1365-313X.2003.01954.x

Meier, S., Bastian, R., Donaldson, L., Murray, S., Bajic, V., and Gehring, C. (2008). Co-expression and promoter content analyses assign a role in biotic and abiotic stress responses to plant natriuretic peptides. BMC Plant Biol. 8:24. doi: 10.1186/1471-2229-8-24

Meier, S., and Gehring, C. (2008). A guide to the integrated application of online data mining tools for the inference of gene functions at the systems level. Biotechnol. J. 3, 1375-1387. doi: 10.1002/biot.200800142

Meier, S., Ruzvidzo, O., Morse, M., Donaldson, L., Kwezi, L., and Gehring, C. (2010). The Arabidopsis thaliana Wall Associated Kinase-like 10 gene encodes a functional guanylyl cyclase and is co-expressed with pathogen defense related genes. PLoS ONE 5:e8904. doi: 10.1371/journal.pone.0008904

Melotto, M., Underwood, W., and He, S. Y. (2008). Role of stomata in plant innate immunity and foliar bacterial diseases. Annu. Rev. Phytopathol. 46, 101-122. doi: 10.1146/annurev.phyto.121107.104959

Morris, K., Mackerness, S. A., Page, T., John, C. F., Murphy, A. M., Carr, J. P., et al. (2000). Salicylic acid has a role in regulating gene expression during leaf senescence. Plant J. 23, 677-685. doi: 10.1046/j.1365-313x.2000.00836.x

Muckenschnabel, I., Goodman, B. A., Williamson, B., Lyon, G. D., and Deighton, N. (2002). Infection of leaves of Arabidopsis thaliana by Botrytis cinerea: changes in ascorbic acid, free radicals and lipid peroxidation products. J. Exp. Bot. 53, 207-214. doi: 10.1093/jexbot/53.367.207

Nawrath, C., and Metraux, J. P. (1999). Salicylic acid induction-deficient mutants of Arabidopsis express PR-2 and PR-5 and accumulate high levels of camalexin after pathogen inoculation. Plant Cell 11, 1393-1404.

Nimchuk, Z., Marois, E., Kjemtrup, S., Leister, R. T., Katagiri, F., and Dangl, J. L. (2000). Eukaryotic fatty acylation drives plasma membrane targeting and enhances function of several type III effector proteins from Pseudomonas syringae. Cell 101, 353-363. doi: 10.1016/S0092-8674(00)80846-6

Noutoshi, Y., Okazaki, M., Kida, T., Nishina, Y., Morishita, Y., Ogawa, T., et al. (2012). Novel plant immune-priming compounds identified via highthroughput chemical screening target salicylic acid glucosyltransferases in Arabidopsis. Plant Cell 24, 3795-3804. doi: 10.1105/tpc.112.098343

Pyke, K. A., and Page, A. M. (1998). Plastid ontogeny during petal development in Arabidopsis. Plant Physiol. 116, 797-803. doi: 10.1104/pp.116.2.797

Quaglia, M., Fabrizi, M., Zazzerini, A., and Zadra, C. (2012). Role of pathogeninduced volatiles in the Nicotiana tabacum-Golovinomyces cichoracearum 
interaction. Plant Physiol. Biochem. 52, 9-20. doi: 10.1016/j.plaphy.2011. 11.006

Quaglia, M., Moretti, C., Canala, G., and Buonaurio, R. (2011). Alternative control approach against gray mold of Pelargonium zonale. J. Plant Path. 93, 51.

Raskin, I., Ehmann, A., Melander, W. R., and Meeuse, B. J. (1987). Salicylic Acid: a natural inducer of heat production in arum lilies. Science 237, 1601-1602. doi: 10.1126/science.237.4822.1601

Raskin, I., Turner, I. M., and Melander, W. R. (1989). Regulation of heat production in the inflorescences of an Arum lily by endogenous salicylic acid. Proc. Natl. Acad. Sci. U.S.A. 86, 2214-2218. doi: 10.1073/pnas.86.7.2214

Reilly, D. S., Tomassini, N., Bevins, C. L., and Zasloff, M. (1994). A Paneth cell analogue in Xenopus small intestine expresses antimicrobial peptide genes: conservation of an intestinal host-defense system. J. Histochem. Cytochem. 42, 697-704. doi: 10.1177/42.6.8189032

Reuber, T. L., Plotnikova, J. M., Dewdney, J., Rogers, E. E., Wood, W., and Ausubel, F. M. (1998). Correlation of defense gene induction defects with powdery mildew susceptibility in Arabidopsis enhanced disease susceptibility mutants. Plant J. 16, 473-485. doi: 10.1046/j.1365-313x.1998.00319.x

Riboni, M., Galbiati, M., Tonelli, C., and Conti, L. (2013). GIGANTEA enables drought escape response via abscisic acid-dependent activation of the florigens and SUPPRESSOR OF OVEREXPRESSION OF CONSTANS. Plant Physiol. 162, 1706-1719. doi: 10.1104/pp.113.217729

Rodrigues Marques, J. P., Amorin, L., Silva-Junior, G., Bellato Spósito, M., and Appezzato-da Gloria, B. (2014). Structural and biochemical characteristics of citrus flowers associated with defense against a fungal pathogen. AoB Plant 7:plu090. doi: 10.1093/aobpla/plu090

Roeder, A. H., Chickarmane, V., Cunha, A., Obara, B., Manjunath, B. S., and Meyerowitz, E. M. (2010). Variability in the control of cell division underlies sepal epidermal patterning in Arabidopsis thaliana. PLoS Biol. 8:e1000367. doi: 10.1371/journal.pbio. 1000367

Schmid, M., Davison, T. S., Henz, S. R., Pape, U. J., Demar, M., Vingron, M., et al. (2005). A gene expression map of Arabidopsis thaliana development. Nat. Gen. 37, 501-506. doi: 10.1038/ng1543

Shan, L., Thara, V. K., Martin, G. B., Zhou, J. M., and Tang, X. (2000). The pseudomonas AvrPto protein is differentially recognized by tomato and tobacco and is localized to the plant plasma membrane. Plant Cell 12, 2323-2338. doi: 10.1105/tpc.12.12.2323

Simpson, G. G., and Dean, C. (2002). Arabidopsis, the Rosetta stone of flowering time? Science 296, 285-289. doi: 10.1126/science.296.5566.285

Smyth, D. R., Bowman, J. L., and Meyerowitz, E. M. (1990). Early flower development in Arabidopsis. Plant Cell 2, 755-767. doi: 10.1105/tpc.2.8.755

Smyth, G. K. (2004). Linear models and empirical bayes methods for assessing differential expression in microarray experiments. Stat. Appl. Gen. Mol. Biol. 3:Article3. doi: 10.2202/1544-6115.1027

Smyth, G. K., Michaud, J., and Scott, H. S. (2005). Use of withinarray replicate spots for assessing differential expression in microarray experiments. Bioinformatics 21, 2067-2075. doi: 10.1093/bioinformatics/ bti270

Sorek, N., Bloch, D., and Yalovsky, S. (2009). Protein lipid modifications in signaling and subcellular targeting. Curr. Opin. Plant Biol. 12, 714-720. doi: 10.1016/j.pbi.2009.09.003

Staff, L., Hurd, P., Reale, L., Seoighe, C., Rockwood, A., and Gehring, C. (2012). The hidden geometries of the Arabidopsis thaliana epidermis. PLOS ONE 7:e43546. doi: 10.1371/journal.pone.0043546

Stulemeijer, I. J., and Joosten, M. H. (2008). Post-translational modification of host proteins in pathogen-triggered defence signalling in plants. Mol. Plant Pathol. 9, 545-560. doi: 10.1111/j.1364-3703.2008.00468.x
Thomma, B. P., Eggermont, K., Penninckx, I. A., Mauch-Mani, B., Vogelsang, R., Cammue, B. P., et al. (1998). Separate jasmonate-dependent and salicylate-dependent defense-response pathways in Arabidopsis are essential for resistance to distinct microbial pathogens. Proc. Natl. Acad. Sci. U.S.A. 95, 15107-15111. doi: 10.1073/pnas.95.25.15107

Thomma, B. P. H. J., Eggermont, K., Tierens, K. F. M. J., and Broekaert, W. F. (1999). Requirement of functional ethylene-insensitive 2 gene for efficient resistance of Arabidopsis to infection by Botrytis cinerea. Plant Physiol. 12, 1093-1101. doi: 10.1104/pp.121.4.1093

Traas, J., Hulskamp, M., Gendreau, E., and Hofte, H. (1998). Endoreduplication and development: rule without dividing? Curr. Opin. Plant Biol. 1, 498-503. doi: 10.1016/S1369-5266(98)80042-3

Veronese, P., Chen, X., Bluhm, B., Salmeron, J., Dietrich, R., and Mengiste, T. (2004). The BOS loci of Arabidopsis are required for resistance to Botrytis cinerea infection. Plant J. 40, 558-574. doi: 10.1111/j.1365-313X.2004. 02232.x

Vlot, A. C., Dempsey, D. A., and Klessig, D. F. (2009). Salicylic Acid, a multifaceted hormone to combat disease. Annu. Rev. Phytopathol. 47, 177-206. doi: 10.1146/annurev.phyto.050908.135202

Voelckel, C., Borevitz, J. O., Kramer, E. M., and Hodges, S. A. (2010). Within and between whorls: comparative transcriptional profiling of Aquilegia and Arabidopsis. PLoS ONE 5:e9735. doi: 10.1371/journal.pone.0009735

Warner, M., Thiel, B. L., and Donald, A. M. (2000). The elasticity and failure of fluid-filled cellular solids: theory and experiment. Proc. Natl. Acad. Sci. U.S.A. 97, 1370-1375. doi: 10.1073/pnas.020501797

Wettenhall, J. M., Simpson, K. M., Satterley, K., and Smyth, G. K. (2006). affylmGUI: a graphical user interface for linear modeling of single channel microarray data. Bioinformatics 22, 897-899. doi: 10.1093/bioinformatics/btl025

Yu, D., Chen, C., and Chen, Z. (2001). Evidence for an important role of WRKY DNA binding proteins in the regulation of NPR1 gene expression. Plant Cell 13, 1527-1540. doi: 10.1105/tpc.13.7.1527

Zhang, W., He, S. Y., and Assmann, S. M. (2008). The plant innate immunity response in stomatal guard cells invokes G-protein-dependent ion channel regulation. Plant J. 56, 984-996. doi: 10.1111/j.1365-313X.2008. 03657.x

Zimmermann, P., Hirsch-Hoffmann, M., Hennig, L., and Gruissem, W. (2004). GENEVESTIGATOR. Arabidopsis microarray database and analysis toolbox. Plant Physiol. 136, 2621-2632. doi: 10.1104/pp.104.046367

Conflict of Interest Statement: The authors declare that the research was conducted in the absence of any commercial or financial relationships that could be construed as a potential conflict of interest.

Received: 21 November 2014; accepted: 30 January 2015; published online: 20 February 2015.

Citation: Ederli L, Dawe A, Pasqualini S, Quaglia M, Xiong L and Gehring C (2015) Arabidopsis flower specific defense gene expression patterns affect resistance to pathogens. Front. Plant Sci. 6:79. doi: 10.3389/fpls.2015.00079

This article was submitted to Plant Systems and Synthetic Biology, a section of the journal Frontiers in Plant Science.

Copyright (c) 2015 Ederli, Dawe, Pasqualini, Quaglia, Xiong and Gehring. This is an open-access article distributed under the terms of the Creative Commons Attribution License (CC BY). The use, distribution or reproduction in other forums is permitted, provided the original author(s) or licensor are credited and that the original publication in this journal is cited, in accordance with accepted academic practice. No use, distribution or reproduction is permitted which does not comply with these terms. 